 \\ OF MEDICAL AND BIOLOGICAL RESHARCH \\ www.bjournal.com.br
}

ISSN 0100-879X

Volume 45 (2) 93-178 February 2012

BIOMEDICAL SCIENCES

AND

CLINICAL INVESTIGATION

Braz J Med Biol Res, February 2012, Volume 45(2) 153-157

doi: 10.1590/S0100-879X2012007500011

Use of the polymerase chain reaction to detect Mycobacterium leprae in urine

K.R. Caleffi, R.D.C. Hirata, M.H. Hirata, E.R. Caleffi, V.L.D. Siqueira and R.F. Cardoso

The Brazilian Journal of Medical and Biological Research is partially financed by

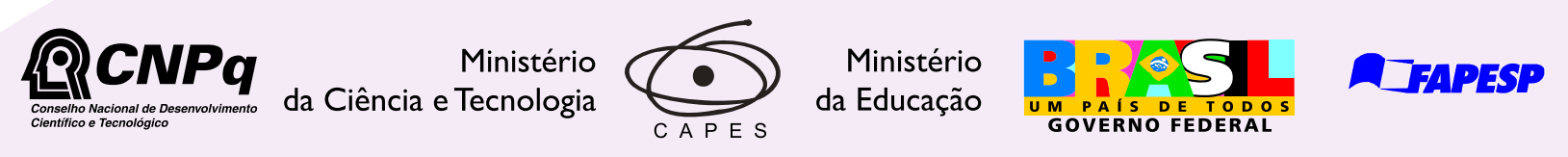

Institutional Sponsors
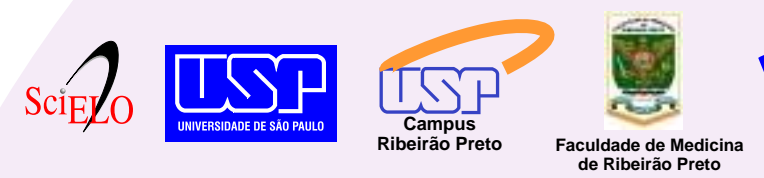

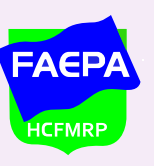

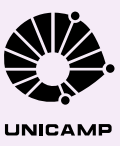

Ф SHIMADZu

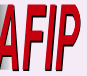

Associaçăo
Fundo
de Incentivo

Explore High - Performance MS Orbitrap Technology

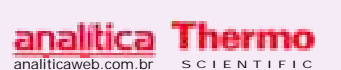




\title{
Use of the polymerase chain reaction to detect Mycobacterium leprae in urine
}

\author{
K.R. Caleffi ${ }^{1}$, R.D.C. Hirata ${ }^{2}$, M.H. Hirata ${ }^{2}$, E.R. Caleffi ${ }^{1}$, \\ V.L.D. Siqueira ${ }^{1}$ and R.F. Cardoso ${ }^{1}$ \\ 1Departamento de Análises Clínicas e Biomedicina, Universidade Estadual de Maringá, Maringá, PR, Brasil \\ ${ }^{2}$ Departamento de Análises Clínicas e Toxicológicas, Universidade de São Paulo, São Paulo, SP, Brasil
}

\begin{abstract}
Leprosy is an infectious disease caused by Mycobacterium leprae. The polymerase chain reaction (PCR) has been applied to detect $M$. leprae in different clinical samples and urine seems to be attractive for this purpose. PCR was used to improve the sensitivity for diagnosing leprosy by amplifying a 151-bp PCR fragment of the M. leprae pra gene (PCR-Pra) in urine samples. Seventy-three leprosy patients ( 39 males and 34 females, 14 to 78 years old) were selected for leprosy diagnosis at a reference laboratory in Maringá, PR, Brazil. Of these, 36 were under anti-leprosy multidrug therapy with dapsone and rifampicin for tuberculoid (TT) and dapsone, rifampicin and clofazimine for borderline (BB) and lepromatous (LL) forms. The control group contained 50 healthy individuals without any clinical history of leprosy. DNA isolated from leprosy patients' urine samples was successfully amplified by PCR-Pra in $46.6 \%$ (34/73) of the cases. The positivity of PCR-Pra for patients with the TT form was $75 \%$ for both patients under treatment and non-treated patients $(P=0.1306)$. In patients with the LL form, PCR-Pra positivity was 52 and $30 \%$ for patients under treatment and non-treated patients, respectively $(P=0.2386)$. PCR-Pra showed a statistically significant difference in detecting $M$. leprae between the TT and LL forms of leprosy in patients under treatment $(P=0.0033)$. Although the current study showed that the proposed PCR-Pra has some limitations in the detection of $M$. leprae, this method has the potential to be a useful tool for leprosy diagnosis mainly in TT leprosy where the AFB slit-skin smear is always negative.
\end{abstract}

Key words: PCR; Leprosy; Mycobacterium leprae; Urine; TT leprosy; LL leprosy

\section{Introduction}

The polymerase chain reaction (PCR) has been applied to detect Mycobacterium leprae in different clinical samples, such as slit-skin smear (1), blood (2), nasal cavity $(3,4)$, skin tissues $(2,5)$, and urine $(6)$ for the improvement of the laboratory diagnosis of leprosy. PCR targets are genes that encode protein antigens of $36 \mathrm{kDa}$, known as proline-rich antigen (pra) $(2,6,7)$, of $18 \mathrm{kDa}(8), 85 \mathrm{kDa}(5)$, $65 \mathrm{kDa}(9), 16 \mathrm{~S}$ rRNA (1), and repetitive sequences (10) to detect $M$. leprae.

Some studies have reported the presence of mycobacterial DNA in urine $(6,11)$, a fact that makes this clinical specimen attractive for the detection of $M$. leprae DNA. This is due to the fact that urine samples are easily collected and enhance patient adherence when compared to the distressing and traumatic slit-skin smear.

Parkash et al. (6) detected M. leprae DNA in the urine of leprosy patients when they used primers proposed by Hartskeerl et al. (7), which amplified a large fragment of
DNA (530 bp) of the pra encoding gene, even though the sample studied had a limited number of individuals. As small fragments of bacterial DNA may be found in patient urine samples (10), the use of this kind of clinical samples and primer set to detect a smaller fragment of $M$. leprae should be better evaluated since the amplification of a smaller DNA fragment may improve the sensitivity of the PCR assay, as pointed out by Goulart et al. (12).

As the structure of the primers can be critical for the PCR assay, in the current study we evaluated a new primerPCR for the detection of the M. leprae pra gene (PCR-Pra) in urine samples.

\section{Material and Methods}

\section{Study population}

Seventy-three patients from northwestern Paraná State with a clinical diagnosis of leprosy were selected at

Correspondence: R.F. Cardoso, Departamento de Análises Clínicas e Biomedicina, Universidade Estadual de Maringá, Av. Colombo, 5790, 87020-900 Maringá, PR, Brasil. Fax: +55-44-3011-4797. E-mail: rfcardoso@uem.br

Received August 23, 2011. Accepted January 19, 2012. Available online February 3, 2012. Published February 17, 2012. 
Laboratório de Ensino e Pesquisa em Análises Clínicas (LEPAC), Universidade Estadual de Maringá (UEM), PR, Brazil, from June 2006 to June 2007. Individuals with a clinical and laboratory diagnosis by microscopy (Ziehl-Gabett) were included. Individuals with kidney or vascular diseases were excluded. Patients were classified by physicians using clinical signs and bacteriological criteria and assigned to the following leprosy forms according to Ridley and Jopling (13): tuberculoid (TT, $N=12$ ), borderline-borderline (BB, $N$ =14), lepromatous ( $L L, N=45$ ), and indeterminate (II, $N=$ 2). Thirty-two patients were under anti-leprosy therapy with dapsone, rifampicin and clofazimine for multibacillary forms (slit-skin smear-positive BB and LL patients) and 4 were treated with dapsone and rifampicin for paucibacillary forms (slit-skin smear-negative TT and II patients). The variables age, gender, and family history of non-treated leprosy and anti-leprosy therapy were analyzed.

A control group consisted of 50 healthy individuals without any clinical history of leprosy and without any cases of the disease in their families.

The study was approved by the Ethics Committee of Universidade Estadual de Maringá (protocol No. 131/2006). All participants approved the research protocol and gave informed written consent.

\section{DNA extraction from urine samples}

Two first-emission urine samples (approximately $12 \mathrm{~mL}$ each) were collected from all participants on consecutive days, homogenized and placed in a boiling water bath for 10 $\mathrm{min}$ and then centrifuged at $12,000 \mathrm{~g}$ for $20 \mathrm{~min}$. DNA extraction was carried out as described by Sechi et al. (11).

\section{PCR-Pra}

The primers Pra1 (5'-ATCCGCTCACTGCCTAAGGA-3') and Pra2 (5'-TGCGTGATATCAGTGACGGAC-3') were designed to amplify a 151-bp segment of the M. leprae pra gene (GenBank accession No. X65546.1). The sequences were aligned using the Prime Premier ${ }^{\circledR}$ V. 5.0 software (Premier Biosoft International, USA). PCR-Pra assays were performed using $5 \mu \mathrm{L}$ template in $20 \mu \mathrm{L}$ of a reaction mixture containing $200 \mathrm{nM}$ primers (Integrated DNA Technologies, USA) and PCR Master Mix (Promega Corporation, USA) according to manufacturer instructions. The amplification was carried out in an Eppendorf thermocycler (Mastercycler $^{\circledR}$ gradient PCR, Germany) using an initial cycle of 5 min at $95^{\circ} \mathrm{C}, 35$ cycles of $60 \mathrm{~s}$ at $95^{\circ} \mathrm{C}, 60 \mathrm{~s}$ at $54^{\circ} \mathrm{C}, 60$ $\mathrm{s}$ at $72^{\circ} \mathrm{C}$, and a final extension of $10 \mathrm{~min}$ at $72^{\circ} \mathrm{C}$. PCR products were separated by $2 \%$ agarose gel electrophoresis in Tris-borate-EDTA (TBE) buffer for $1 \mathrm{~h}$ at $100 \mathrm{~V}$ and the gels were stained with ethidium bromide. A 100-bp DNA Ladder (Invitrogen Life Technologies, Brazil) was used as a molecular marker. Positive and negative controls were included in all amplifications. Five microliters of DNA extracted $(0.15 \mu \mathrm{g} / \mathrm{mL})$ from an armadillo's skin lesion was added to the PCR reagents for the positive controls, and
$5 \mu \mathrm{L}$ TBE was added to the PCR reagents to serve as the negative controls.

\section{Specificity and sensitivity of the PCR}

The specificity of the PCR-Pra for the detection of $M$. leprae in urine was evaluated using DNA extracted from $M$. leprae obtained from a skin lesion of an armadillo experimentally infected and kindly supplied by the animal laboratory of Institute Lauro de Souza Lima (São Paulo, Brazil). Reference strains of $M$. tuberculosis H37Rv (ATCC 27.294), M. bovis AN5, M. gordonae (Lacen/Pr), M. avium (ATCC 13.950), M. kansasii (Lacen/Pr), M. fortuitum (Lacen/ Pr), M. szulgai (Lacen/Pr), M. flavescens (Lacen/Pr), and M. smegmatis (Lacen/Pr) were also used. The DNA was extracted using a phenol-chloroform method (14). Sensitivity was determined using total DNA ( $M$. leprae) obtained from a skin lesion of an armadillo $(90 \mu \mathrm{g} / \mathrm{mL})$ and diluted $1: 100(0.90 \mu \mathrm{g} / \mathrm{mL}), 1: 300(0.30 \mu \mathrm{g} / \mathrm{mL}), 1: 600(0.15 \mu \mathrm{g} /$ $\mathrm{mL})$, and $1: 1200(0.075 \mu \mathrm{g} / \mathrm{mL})$. The detection of PCR inhibitors in urine samples was carried out by the addition of $5 \mu \mathrm{L}$ DNA extracted $(0.15 \mu \mathrm{g} / \mathrm{mL})$ from a skin lesion of an armadillo to a $20-\mu \mathrm{L}$ aliquot of each DNA extracted from urine samples.

\section{Data analysis}

Clinical samples were considered to be positive for the presence of $M$. leprae DNA when a single band of PCR product (151 bp) was observed and considered to be negative by the absence of amplification after the observation of PCR controls. In the absence of amplification of the positive controls, samples and their respective controls were amplified using diluted (1:2) DNA extracted from urine samples.

Data were analyzed with non-parametric tests for proportions, McNemar test, chi-square test, and G test, using BioEstat 5.0 (Federal University of Pará, Brazil), with the level of significance set at $\mathrm{P}<0.05$.

\section{Results}

The mean age of patients with leprosy was 46 years (range: 14-78) and a higher prevalence was observed in women $(51.4 \%)$ and men $(58.3 \%)$ among the non-treated patients and patients under treatment, respectively. A higher proportion of patients $(41.7 \%)$ with a family history of leprosy was observed among patients under treatment. The highest positivity of PCR-Pra was observed in male patients aged 31 to 60 years and in patients with a family history of leprosy. However, no significant difference was observed between patients under treatment and non-treated patients considering gender, age, family history of leprosy, and positivity of PCR-Pra ( $P>0.005$; Table 1$)$.

PCR-Pra was specific for the detection of $M$. leprae and detected DNA up to $1: 600(0.15 \mu \mathrm{g} / \mathrm{mL})$ dilution. No amplification was observed in DNA from $M$. tuberculosis, $M$. 
gordonae, M. avium, M. kansasii, M. fortuitum, M. szulgai, $M$. flavescens, $M$. smegmatis, and $M$. bovis.

DNA isolated from urine samples was also successfully amplified by PCR-Pra, which was positive in 46.6\% (34/73) of all patients studied. No significant difference in PCR positivity was observed between patients under treatment and non-treated patients with the TT $(P=0.1306)$ and $L L$ $(P=0.2386)$ forms. The positivity of PCR-Pra was higher in patients under treatment with the TT form $(75 \%)$ than in patients with the LL form $(52 \%)(P=0.0033)$. No significant difference in $M$. leprae detection was observed between patients with the TT and LL forms in the diagnostic phase of leprosy ( $P=0.2889$ ) (Table 2). Initial PCR-Pra inhibition in non-treated leprosy patients was observed in $24.3 \%$ (9/37) of the total samples studied. The diluted DNA extracts (1:2) showed PCR inhibitors in $13.5 \%$ $(5 / 37)$ of samples.

No amplification was observed in the healthy control group (Table 2).

\section{Discussion}

An epidemiological study (15) indicated that adult males and people with a family history of leprosy are more vulnerable to leprosy. In the current study, the PCR-Pra positivity was consistent with the literature, with a higher positivity among males aged 31 to 60 years with a family history of leprosy.

Variation in $M$. leprae PCR positivity has been mainly related to different primers used (5), amplified fragment size (12), amplification techniques (16), and clinical specimens $(2,6)$. The PCR-Pra intended to detect $M$. leprae in urine samples by amplifying a 151-bp DNA fragment of the pra gene, which was smaller than that described by Hartskeerl et al. (7) and other proposed PCR for improving PCR assay sensitivity.

PCR-Pra showed specific detection of $M$. leprae among the other mycobacteria tested and showed overall higher sensitivity $(46.6 \%)$ in detecting $M$. leprae in urine than that obtained by Parkash et al. (6) targeting the pra gene (37.5\%) and Caleffi et al. (17) targeting 85 A-C intergenic region (4.10\%) in previous studies, which amplified a 530- and a 250-bp DNA fragment, respectively. This result suggests that the amplification of a smaller DNA fragment (151 bp) by PCR-Pra may improve the performance of PCR-based methods for detecting $M$. leprae in urine samples, as pointed out by Goulart et al. (12). It is important to emphasize that small fragments of bacterial DNA may be found in urine samples as a result of DNA damage by antimicrobial therapy and/or by its processing and excretion $(10,18)$.

Table 1. Distribution of non-treated leprosy patients and leprosy patients under treatment regarding gender, age, family history of leprosy, and PCRPra results.

\begin{tabular}{lccc}
\hline & $\begin{array}{c}\text { No. of non-treated } \\
\text { patients (\%) }\end{array}$ & $\begin{array}{c}\text { No. of patients } \\
\text { under treatment (\%) }\end{array}$ & $\begin{array}{c}\text { Positive } \\
\text { PCR-Pra (\%) }\end{array}$ \\
\hline $\begin{array}{l}\text { Gender } \\
\text { Female }\end{array}$ & $19(51.4)$ & $15(41.7)$ & $15(44.1)$ \\
Male & $18(48.6)$ & $21(58.3)$ & $19(48.7)$ \\
Age (years) & & & \\
$5-17$ & $1(2.7)$ & $0(0.0)$ & $0(0.0)$ \\
$18-30$ & $2(5.4)$ & $7(19.4)$ & $3(33.3)$ \\
$31-45$ & $10(27.0)$ & $8(22.2)$ & $9(50.0)$ \\
$46-60$ & $18(48.6)$ & $17(47.2)$ & $19(54.3)$ \\
$61-78$ & $6(16.2)$ & $4(11.1)$ & $3(30.0)$ \\
Total & $37(100)$ & & $14(37.8)$ \\
Total & & $36(100)$ & $20(55.5)$ \\
Family history of leprosy & $15(41.7)$ & $14(63.6)$ \\
Yes & $7(18.9)$ & $21(58.3)$ & $20(39.2)$ \\
No & $30(81.1)$ & & \\
\hline
\end{tabular}

PCR-Pra $=$ positivity vs gender, family history of leprosy $(P>0.05$; chisquare test). PCR-Pra positivity vs age ( $>0.05$; $G$ test).

Table 2. Performance of PCR-Pra for the detection of Mycobacterium leprae in urine according to the clinical form of non-treated patients and patients under treatment.

\begin{tabular}{|c|c|c|c|c|c|c|c|c|c|c|c|c|}
\hline & \multicolumn{12}{|c|}{ PCR positivity (\%) } \\
\hline & \multicolumn{5}{|c|}{ Non-treated patients } & \multicolumn{5}{|c|}{ Patients under treatment } & \multirow[t]{2}{*}{ Total } & \multirow{2}{*}{$\frac{\text { Control group }}{\text { Total }}$} \\
\hline & II & TT & BB & LL & Total & II & TT & BB & LL & Total & & \\
\hline PCR-Pra & $(0 / 2)$ & $\begin{array}{l}75.0 \\
(6 / 8)\end{array}$ & $\begin{array}{l}28.6 \\
(2 / 7)\end{array}$ & $\begin{array}{c}30.0 \\
(6 / 20)\end{array}$ & $\begin{array}{c}37.8 \\
(14 / 37)\end{array}$ & $(0 / 0)$ & $\begin{array}{l}75.0 \\
(3 / 4)\end{array}$ & $\begin{array}{l}57.1 \\
(4 / 7)\end{array}$ & $\begin{array}{c}52.0 \\
(13 / 25)\end{array}$ & $\begin{array}{c}55.5 \\
(20 / 36)\end{array}$ & $\begin{array}{c}46.6 \\
(34 / 73)\end{array}$ & $(0 / 50)$ \\
\hline
\end{tabular}

The number of individuals is given in parentheses. II = indeterminate leprosy; TT = tuberculoid leprosy; $\mathrm{BB}=$ borderline leprosy; $\mathrm{LL}=$ lepromatous leprosy. $\mathrm{P}=0.1306$ (McNemar test), $\mathrm{PCR}$ results vs patients with the TT form. $\mathrm{P}=0.2386$ (McNemar test), $\mathrm{PCR}$ results vs patients with the LL form. $P=0.2889$ (McNemar test), PCR results vs non-treated patients with the TT form and the LL form. $P=0.0033$ (McNemar test), PCR results vs patients with the TT and LL forms under treatment. 
Parkash et al. (6) observed high PCR positivity in patients under anti-leprosy treatment $(66.7 \%)$ compared to non-treated patients $(20.0 \%)$. In the present study, in which PCR-Pra was applied to a larger number of patients, the difference between these groups of patients was not statistically significant.

In the case of patients under treatment, PCR-Pra showed a significant difference between the TT and LL forms of leprosy ( $P=0.0033$ ). This result may be associated with the action of the antimicrobial, cell immune response, increased excretion of dead bacilli by the kidneys in the TT form of leprosy, and a higher sensitivity of the PCR-Pra by amplification of a smaller DNA fragment (12). Since the cell immune response, predominant in the TT form, is more efficient in combating the bacilli than the humoral immune response, predominant in the LL form, the excretion of a greater amount of free DNA by the kidneys would be expected to occur in the TT form as reported by Parkash et al. (6) and in the previous study targeting the $85 \mathrm{~A}-\mathrm{C}$ intergenic region using the same clinical samples from non-treated patients (diagnostic phase) (16). However, PCR-Pra positivity showed no statistically significant difference among patients with the TT and LL forms in the diagnostic phase $(P=0.2889)$.

PCR-Pra proved to be highly useful to confirm the diagnosis of leprosy, especially in the TT form (75\% PCR-Pra positivity in patients under treatment and in non-treated patients), where microscopic detection of AFB in slit-skin smears is normally negative owing to the low number of bacilli present in clinical samples (19).

In the current study, certain interfering elements were present in the urine samples, which resulted in PCR inhibi-

\section{References}

1. Phetsuksiri B, Rudeeaneksin J, Supapkul P, Wachapong S, Mahotarn K, Brennan PJ. A simplified reverse transcriptase PCR for rapid detection of Mycobacterium leprae in skin specimens. FEMS Immunol Med Microbiol 2006; 48: 319328.

2. Torres P, Camarena JJ, Gomez JR, Nogueira JM, Gimeno V, Navarro JC, et al. Comparison of PCR mediated amplification of DNA and the classical methods for detection of Mycobacterium leprae in different types of clinical samples in leprosy patients and contacts. Lepr Rev 2003; 74: 18-30.

3. Santos AR, Balassiano V, Oliveira ML, Pereira MA, Santos PB, Degrave WM, et al. Detection of Mycobacterium leprae DNA by polymerase chain reaction in the blood of individuals, eight years after completion of anti-leprosy therapy. Mem Inst Oswaldo Cruz 2001; 96: 1129-1133.

4. Patrocinio LG, Goulart IM, Goulart LR, Patrocinio JA, Ferreira FR, Fleury RN. Detection of Mycobacterium leprae in nasal mucosa biopsies by the polymerase chain reaction. FEMS Immunol Med Microbiol 2005; 44: 311-316.

5. Martinez NA, Britto CFPC, Nery JAC, Scollard D, Truman $\mathrm{R}$, Moraes $\mathrm{MO}$, et al. Evaluation of real-time and conven- tion. Urine normally contains substances such as insoluble amorphous salts, nitrate, urea, proteins, blood, and even high ratios of human genomic DNA, which can inhibit PCR (5). Thus, the effect of PCR inhibitors in urine may have been reduced when the DNA samples were diluted. A significant reduction (10.8\%) in PCR inhibition rate was consequently observed in patients in the diagnostic phase. Since the dilution of $M$. leprae DNA probably occurred simultaneously, detection of the bacillus turned out to be difficult in some cases.

It is noteworthy that the nucleic acids in urine or other clinical specimens detected by PCR do not necessarily indicate the presence of viable $M$. leprae in the human organism (20). PCR results are slow to turn negative after the start of antimicrobial therapy. This is due to the presence of DNA fragments, which remain in circulation for several weeks after death of the bacilli (11). The time period during which $M$. leprae DNA may be excreted in urine is unknown since the bacilli have already been reported to last up to 8 years after the completion of anti-leprosy therapy (3).

PCR-Pra showed some potential as a useful assay for the detection of $M$. leprae DNA in urine samples, with a further asset for the diagnosis of leprosy mainly in the TT form or in inconclusive cases where the AFB slit-skin smear is always negative. PCR-Pra should be evaluated in an extended number of patients from endemic and nonendemic regions to address limitations such as performing a multiplex-PCR in urine with an internal control.

\section{Acknowledgments}

Research supported by CAPES. tional PCR targeting complex 85 genes for detection of Mycobacterium leprae DNA in skin biopsy samples from patients diagnosed with leprosy. J Clin Microbiol 2006; 44: 3154-3159.

6. Parkash O, Singh HB, Rai S, Pandey A, Katoch VM, Girdhar BK. Detection of Mycobacterium leprae DNA for 36-kDa protein in urine from leprosy patients: a preliminary report. Rev Inst Med Trop São Paulo 2004; 46: 275-277.

7. Hartskeerl RA, de Wit MY, Klatser PR. Polymerase chain reaction for the detection of Mycobacterium leprae. J Gen Microbiol 1989; 135: 2357-2364.

8. Chae GT, Kim MJ, Kang TJ, Lee SB, Shin HK, Kim JP, et al. DNA-PCR and RT-PCR for the 18-kDa gene of Mycobacterium leprae to assess the efficacy of multi-drug therapy for leprosy. J Med Microbiol 2002; 51: 417-422.

9. Plikaytis BB, Gelber RH, Shinnick TM. Rapid and sensitive detection of Mycobacterium leprae using a nested-primer gene amplification assay. J Clin Microbiol 1990; 28: 19131917.

10. Donoghue HD, Holton J, Spigelman M. PCR primers that can detect low levels of Mycobacterium leprae DNA. J Med 
Microbiol 2001; 50: 177-182.

11. Sechi LA, Pinna MP, Sanna A, Pirina P, Ginesu F, Saba $\mathrm{F}$, et al. Detection of Mycobacterium tuberculosis by PCR analysis of urine and other clinical samples from AIDS and non-HIV-infected patients. Mol Cell Probes 1997; 11: 281285.

12. Goulart IM, Cardoso AM, Santos MS, Goncalves MA, Pereira JE, Goulart LR. Detection of Mycobacterium leprae DNA in skin lesions of leprosy patients by PCR may be affected by amplicon size. Arch Dermatol Res 2007; 299: 267-271.

13. Ridley DS, Jopling WH. Classification of leprosy according to immunity. A five-group system. Int J Lepr Other Mycobact Dis 1966; 34: 255-273.

14. Cardoso RF, Cooksey RC, Morlock GP, Barco P, Cecon L, Forestiero $\mathrm{F}$, et al. Screening and characterization of mutations in isoniazid-resistant Mycobacterium tuberculosis isolates obtained in Brazil. Antimicrob Agents Chemother 2004; 48: 3373-3381.

15. Chen XS, Li WZ, Jiang C, Ye GY. Leprosy in China: epidemiological trends between 1949 and 1998. Bull World Health
Organ 2001; 79: 306-312.

16. Kramme S, Bretzel G, Panning M, Kawuma J, Drosten C. Detection and quantification of Mycobacterium leprae in tissue samples by real-time PCR. Med Microbiol Immunol 2004; 193: 189-193.

17. Caleffi KR, Hirata RD, Hirata MH, Caleffi ER, Peixoto PR, Sposito $\mathrm{FL}$, et al. Evaluation of $85 \mathrm{~A}-\mathrm{C}$ intergenic region $\mathrm{PCR}$ primers for detection of Mycobacterium leprae DNA in urine samples. Int J Dermatol 2010; 49: 717-718.

18. Jamil S, Keer JT, Lucas SB, Dockrell HM, Chiang TJ, Hussain $\mathrm{R}$, et al. Use of polymerase chain reaction to assess efficacy of leprosy chemotherapy. Lancet 1993; 342: 264268.

19. Banerjee S, Ray D, Bandyopadhyay D, Gupta S, Gupta S, Ghosal C, et al. Development and application of a new efficient and sensitive multiplex polymerase chain reaction (PCR) in diagnosis of leprosy. J Indian Med Assoc 2008; 106: 436-440.

20. Speers DJ. Clinical applications of molecular biology for infectious diseases. Clin Biochem Rev 2006; 27: 39-51. 